\title{
KORELASI MODAL TERHADAP KONTESTASI ARENA DAN PRAKTIK FEBA SUKMANA PENULIS NOVEL HOLLAND: ONE FINE DAY IN LEIDEN DALAM ASPEK PASAR, NARASI, DAN PENGGUNAAN BAHASA
}

\author{
Hary Sulistyo \\ Sastra Indonesia FIB UNS \\ Email: sulistyohary@yahoo.com
}

\begin{abstract}
Abstrak
Penelitian ini untuk melihat Implementasi modal Feba Sukmana dalam aspek narasi dan penggunaan bahasa. Yang pertama terkait modal kulturalnya dimana ia terlahir dari keluarga seni yang membuatnya terbiasa membaca buku dan menulis diary. Yang kedua terkait modal pendidikannya ketika studi Sastra Belanda di Universitas Indonesia dan S2 di Leiden University. Yang ketiga terkait habitus yang ia bangun sejak kecil hingga menulis novel Holand: One Fine Day in Leiden. Hubungan antara pendidikan dan penggunaan bahasa terletak pada pemilihan bahasa, dan terlihat dalam kemampuannya membangun narasi, mendeskripsikan suatu keadaan, dan penggunaan bahasa asing seperti Inggris dan Belanda. Lebih dari itu, penjabaran kondisi dan wawasan di Belanda tentu terkait pula dengan studi atau pendidikannya.
\end{abstract}

Kata kunci: Feba Sukmana, modal, kontestasi arena, hubungan pendidikan dan bahasa.

\section{Abstract}

This research focuses to show Feba Sukmana's modal implementation in narration and language use aspect. The first thing is about her cultural asset. She was born from art family and it made her likes reading stories and writing diary. The second asset is her Dutch insight when she studied in University of Indonesia and master program in Leiden University. The third asset is about her habbit built since she was child, started from writing diary until writing Holland: One Fine Day In Leiden novel. The relation between educational back.ground and language using is on the language choice. It is showed in the ability of building narration, describing condition, using foreign language such as English and Dutch. Moreover, describing Dutch condition and concept has so much relevance to the educational background.

Keywords: Feba Sukmana, asset, the field of contestation, and study and language relevance.

\section{Pendahuluan}

Feba Sukmana, penulis novel Holland: One Fine Day in Leiden, merupakan penulis yang relatif baru dalam belantika kesusastraan Indonesia. Feba, panggilan akrab Feba Sukmana, mulai dikenal sebagai penulis di Indonesia melalui program Setiap Tempat Punya Cerita yang digagas oleh Gagas Media bekerja sama dengan Bukune dimana novel tersebut terbit pada tahun 2013. Novel dengan jumlah 300 halaman itu saat ini sudah banyak menghiasi toko buku di Indonesia.

Diakui oleh Feba Sukmana dalam sesi wawancara di kota Rotterdam, yaitu kota dimana saat ini ia tinggal, bahwa ia menulis novel tersebut karena tawaran secara langsung oleh salah satu redaktur Gagas Media. Hal-hal yang harus dikedepankan adalah hal-hal terkait dengan hujan, kanal-kanal, dan tentu terkait dengan kota dimana Feba Sukmana tinggal dan menempuh studi, yaitu Leiden. Hal yang menarik untuk dikedepankan dalam tulisan ini adalah perihal ia mendapatkan tawaran secara langsung dari redaktur, mengingat ia tidak memiliki karya terkenal baik dalam bentuk puisi, cerpen, ataupun novel.

Novel Holland: One Fine Day in Leiden menceritakan mengenai kisah seorang mahasiswa Indonesia yang studi di Belanda. Selain masalah dunia perkuliahan di Leiden University, novel tersebut juga menceritakan banyak hal mengenai Belanda seperti dalam hal cuaca, budaya, tempat-tempat, dan orangorang yang berada di sekitar kehidupan tokoh. Baik teman-teman kuliah tokoh Kara sebagai tokoh utama dalam novel maupun orang-orang yang memiliki hubungan khusus dengan tokoh 
utama seperti kekasihnya dan keluarganya.

Selain mengenai tawaran yang diberikan kepadanya, cerita mengenai Belanda, dan terkait fokus penceritaan mengenai dunia perkuliahan, penggunaan bahasa dalam novel tersebut juga merupakan hal yang menarik untuk diperhatikan. Bourdieu menjelaskan bahwa bahasa erat kaitanya dengan strata seseorang, baik hubungannya dengan pendidikan maupun dalam hal ekonomi (Wilkes, 1990: 161). Artinya, baik tawaran, penceritaan mengenai Belanda dan dunia perkuliahan, maupun penggunaan bahasa yang tercermin di dalamnya, memiliki korelasi karena semua itu tentu berkaitan dengan trajektori yang dimiliki oleh Feba Sukmana. Trajektori yang dimiliki oleh Feba Sukmana tentu terkait dengan akumulasi modal yang ia miliki dan ia bangun yang menjadi kebiasaannya atau habitusnya sehingga mampu menuliskan novel tersebut.

Novel yang setipe dengan Holland: One Fine Day in Leiden karya Feba Sukmana, baik dalam periode penerbitan, pokok penceritaan, maupun karakteristiknya adalah novel terbitan Bentang Pustaka dengan judul Negeri van Oranje (2009) yang ditulis oleh Wahyuningrat, dkk. Novel ini juga bercerita mengenai Negeri Tulip dimana fokus pada novel ini lebih menceritakan mengenai pengalaman beberapa mahasiswa Indonesia (lima orang) yang merupakan implementasi dari empat penulisnya. Latar yang dibangun tidak hanya terfokus di sebuah kota, tetapi juga beberapa tempat dimana tokohtokoh dalam cerita tersebut tinggal dan studi di beberapa universitas.

Ada perbandingan yang menarik tentunya di antara kedua novel tersebut. Hal ini perlu diulas sebagai bentuk kontestasi arena atau bentuk kontestasi penulis yang menulis dalam ranah penceritaan yang sama. Sama yang dimaksud lebih pada bahasan penceritaan, yaitu Belanda dan dunia perkuliahan. Selain itu, kesamaan arena yang dimaksud juga terkait dengan relasi waktu penerbitan keduanya yang tidak terlampau jauh. Di sisi lain, pola novel tersebut juga mengenai tulisan orang Indonesia yang menceritakan pengalaman dan perjalanan mereka di Belanda.

Implementasi bahasa yang digunakan di dalam novel Holland: One Fine Day in Leiden merupakan bentuk praktik. Seperti yang telah dijelaskan sebelumnya, bahasa akan mencerminkan karakteristik penulisnya. Bagaimana trajektori yang merupakan legitimasi dari akumulasi modal-modal yang dibangun dan dimiliki penulis, arena atau ranah yang dikuasai penulis, dan bahasa serta narasi sebagai bentuk media dalam novelnya memiliki kaitan yang erat.

Tulisan ini akan melihat bagaimana kaitan antara modal-modal Feba Sukmana sebagai seorang penulis dan kontestasinya dalam arena atau ranah yang ia tempati dengan pengarang atau karya lain, dan kaitan penggunaan bahasa di dalam novelnya sebagai bentuk praktik. Teori yang digunakan adalah Sosiologi Pierre Bourdieu karena teori tersebut mengakomodasi hubungan antara akumulasi kapasitas seseorang sebagai agensi yang bersumber dari modal-modal dan habitus atau kebiasaan yang terbangun dalam ranah tertentu dengan bentuk praktik yang dihasilkan.

\section{Konseptualisasi Teori}

Dalam hal menjelaskan hubungan antara agensi dan struktur yang tidak linier, Bourdieu mengajukan konsep khasnya yaitu habitus dan ranah (field). Bourdieu (1979: vii) mengartikan habitus sebagai suatu sistem disposisi yang berlangsung lama dan berubahubah dan berfungsi sebagai basis generatif bagi praktik-praktik yang terstruktur dan terpadu secara objektif. Sementara itu, ranah oleh Bourdieu diartikan sebagai jaringan relasi antarposisi-posisi objektif dalam suatu tatanan sosial yang hadir terpisah dari kesadaran dan kehendak individual. Habitus dan ranah merupakan perangkat konseptual utama yang krusial bagi karya Bourdieu yang ditopang oleh sejumlah ide lain, seperti kekuasaan simbolik, strategi, dan perebutan (kekuasaan simbolik dan material), beserta beragam jenis modal 


\section{Jurnal Poetika Vol. III No. 2, Desember 2015}

(ekonomi, budaya, dan simbolik).

Habitus bisa dikatakan sebagai ketidaksadaran-kultural, yakni pengaruh sejarah yang secara tak sadar dianggap alamiah. Habitus adalah produk sejarah setelah manusia lahir dan berinteraksi dengan masyarakat dalam ruang dan waktu tertentu. Habitus merupakan hasil pembelajaran lewat pengasuhan, aktivitas bermain, dan juga pendidikan masyarakat dalam arti luas. Pembelajaran ini terjadi secara halus, tak disadari dan tampil sebagai hal wajar, sehingga seolah-olah sesuatu yang alamiah, seakan-akan terberi oleh alam atau "sudah dari sananya".

Habitus mendasari ranah yang merupakan jaringan relasi antarposisi-posisi objektif dalam suatu tatanan sosial yang hadir terpisah dari kesadaran individual. Ranah bukan ikatan intersubjektif antara individu melainkan semacam hubungan yang terstruktur dan tanpa disadari mengatur posisi-posisi individu dan kelompok dalam tatanan masyarakat secara spontan.

Ranah mengisi ruang sosial. Istilah ruang sosial mengacu pada keseluruhan konsepsi tentang dunia sosial. Konsep ini menganalogikan realitas sosial sebagai sebuah ruang dan pemahamannya menggunakan pendekatan tipologi. Ruang sosial dapat dikonsepsi terdiri dari beragam ranah yang memiliki sejumlah hubungan satu sama lain, serta sejumlah titik kontak. Ruang sosial individu dikaitkan melalui waktu (trajektori kehidupan) dengan serangkaian ranah orang-orang yang berebut berbagai bentuk modal. Dalam ruang sosial ini, individu dengan habitusnya berhubungan dengan individu lain, dan berbagai realitas sosial yang menghasilkan tindakan-tindakan sesuai dengan ranah dan modal yang dimilikinya.

Praktik merupakan suatu produk dari relasi antara habitus sebagai produk sejarah dan ranah yang juga merupakan produk sejarah. Pada saat bersamaan, habitus dan ranah juga merupakan produk dari medan daya-daya yang ada di masyarakat. Mereka yang memiliki modal dan habitus yang sama dengan kebanyakan individu akan lebih mampu melakukan tindakan mempertahankan atau mengubah struktur dibandingkan dengan mereka yang tidak memiliki modal. Secara ringkas, Bourdieu menyatakan rumus generatif yang menerangkan praktik sosial dengan persamaan: (habitus x modal) + ranah: praktik (Bourdieu 1984: 101). Rumus ini mengganti setiap relasi sederhana antara individu dan struktur dengan relasi antara habitus dan ranah yang melibatkan modal (Takwin, 2009: $\mathrm{xxi)}$.

Berdasarkan pengertian habitus dan ranah, pemahaman terhadap interaksi struktur objektif dan struktur subjektif serta mekanisme kerjanya pada diri manusia dan kehidupan sosial, Bourdieu mengajukan penjelasan tentang doxa yang pengertiannya menyerupai ideologi. Doxa adalah sejenis tatanan sosial dalam diri individu yang stabil dan terikat pada tradisi serta kekuasaan yang sepenuhnya ternaturalisasi dan tidak dipertanyakan. Dalam tulisannya, Bourdieu menyatakan pengertian doxa sebagai:

Kesamaan struktur objektif dan struktur yang terinternalisasi yang memerlukan ilusi pemahaman segera, karakteristik pengalaman praksis dari dunia yang tak asing lagi dan pada saat yang sama tidak menyertakan pertanyaan-pertanyaan yang mungkin dapat dikenakan terhadap pengalaman itu (Bourdieu, 1990:20).

Konseptualisasi teori dalam tulisan ini terkait vitur-vitur utama teori Pierre Bourdieu. Meskipun demikian, aplikasi teori tidak bisa sepenuhnya dilakukan mengingat terlalu luasnya jangkauan teori tersebut. Di sisi lain upaya mencari relevansi antara modal dan kontestasi arena dan praktik penulis yang menekankan pada aspek pendidikan dan bahasa adalah hal yang menarik dicoba, mengingat fokus utama teori sosiologi Bourdieu memang bertumpu pada dunia pendidikan, dan melihat pula aspek bahasa dimana penggunaan bahasa oleh seorang agensi terkait erat dengan diri agensi tersebut. 


\section{Modal Feba Sukmana Penulis Novel Holland: One Fine Day in Leiden}

Feba Sukmana adalah seorang penulis yang menyelesaikan studi S1 jurusan Sastra Belanda di Universitas Indonesia pada tahun 2005 dan menempuh studi S2 dalam kajian yang sama pada tahun 2007 di Leiden University, Belanda. Saat ini penulis tersebut tinggal di kota Rotterdam Belanda sebagai pengajar Bahasa Indonesia di Volkuniversiteit Rotterdam. Dalam sistem pendidikan di Indonesia, Volksuniversiteit selevel dengan Universitas Terbuka.

Sejak kecil, Feba (panggilan akrab Feba Sukmana) sudah akrab dengan dunia seni. Bapaknya yang merupakan seorang guru memiliki hobi melukis, dan hal itu ditularkan kepada Feba. Sebagai seorang guru, bapaknya sering membawakan bacaan berupa buku cerita, sehingga membentuk karakteristik Feba yang dekat dengan dunia seni terutama dalam hal dunia cerita.

Kebiasaan Feba Sukmana sejak kecil adalah menulis diary. Lengkap sudah modal kultural Feba dengan dunia seni yang membentuk karakternya. Dimulai dari terlahir dalam keluarga seni, sering dibawakan buku cerita oleh bapaknya yang berprofesi sebagai seorang guru, dan kebiasaannya menulis diary. Hal ini tentu berkorelasi dengan habitus Feba, atau kebiasaannya dalam hal tulis-menulis cerita dan menghasilkan trajektori, yaitu ketika salah seorang redaktur Gagas Media, teman kuliahnya di Universitas Indonesia memberikan tawaran untuk mengirimkan naskah novel pertamanya yang akhirnya mampu melambungkan namanya.

Selain modal kultural yang telah dipaparkan, modal Feba Sukmana sebagai seorang penulis juga berkaitan dengan modal pendidikan dimana modal Feba Sukmana erat kaitannya. Proses awal publikasi karya-karya Feba Sukmana adalah melalui mading-mading sekolah ketika masih SMP dalam bentuk puisi. Berikutnya berkembang dalam bentuk cerpen dengan media yang sama, yaitu majalah dinding ketika telah memasuki tingkatan SMA. Dengan demikian, media-media atau fasilitas sekolah dimana ia menuntut ilmu, baik ketika SMP maupun SMA, telah menjadi tempaan dirinya untuk menjadi seorang penulis.

Kondisi Feba Sukmana sebagai anak seorang guru juga berpengaruh terhadap modal pendidikannya. Dalam hal ini, arahanarahan yang dilakukan oleh orang tua Feba Sukmana tentunya cenderung kuat dalam dunia pendidikan yang terimplementasi pula ketika ia bisa studi di Universitas Indonesia sebagai salah satu kampus terbaik di Indonesia dan Leiden University sebagai salah satu kampus terbaik di dunia. Kedekatan Feba Sukmana dengan perbukuan, sebagaimana sejak kecil ia sering kali dibawakan buku oleh bapaknya, membuatnya kuat dalam membaca atau belajar. Hal itu tentu berhubungan dengan tingkat intelektualnya, sehingga bisa studi di Universitas Indonesia dan mendapatkan beasiswa S2 di Leiden University karena kemauan belajarnya sudah terbentuk sejak kecil dalam keluarga yang bekerja dalam dunia pendidikan. Artinya, tingkat intelektual Feba Sukmana yang bisa studi di Universitas Indonesia dan Leiden University juga terbentuk dalam proses pendidikan.

Sebagai mahasiswa sastra, Feba Sukmana tentu memiliki pengalaman dalam mempelajari sastra dan budaya. Sebagai pengkaji Sastra Belanda, kondisi kultural maupun perspektif mengenai Belanda tentu ia kuasai. Implementasinya, ketika ia harus menuliskan narasi tentang Belanda dan khususnya kota Leiden dimana ia lama tinggal dan studi, sudah terdapat modal tersendiri baginya.

\section{Arena: Kontestasi Feba Sukmana Penulis Novel Holland: One Fine Day in Leiden dalam Kaitannya dengan Pasar dan Belanda sebagai Pokok Penceritaan}

Novel dengan tema mengenai Belanda yang tidak kalah terkenal dengan novel Holland: One Fine Day in Leiden adalah Negeri van Oranje karya Wahyuningrat, dkk. Novel ini terbit pertama kali pada tahun 2009 oleh penerbit yang 


\section{Jurnal Poetika Vol. III No. 2, Desember 2015}

cukup terkenal, yaitu Bentang Pustaka, dan kini sudah pada cetakan pertama edisi kedua.

Pada bagian ini, analisis akan dilakukan dengan cara membandingkan kedua novel tersebut sebagai bentuk persaingan arena atau ranah (field). Hal itu perlu dilakukan karena tiga alasan, yakni 1.) Kedua novel sama-sama ditulis dengan menggunakan Bahasa Indonesia mengenai Belanda, 2.) Novel tersebut memiliki pola yang sama, yaitu menceritakan pengalaman para penulis ketika tinggal di Belanda, 3.) Kedua novel terbit pada kurun waktu yang relatif sama.

Dalam hal arena atau ranah, Bourdieu menjelaskan bahwa konsepsi ranah tidak dipandang sebagai ranah yang berpagar di sekelilingnya, melainkan lebih sebagai ranah kekuatan. Dengan demikian, penilaian terhadap arena seorang pengarang tentu harus dibandingkan dengan penulis lain. Berikut ini adalah bagan perbandingan antara novel Holland: One Fine Day in Leiden karya Feba Sukmana dan novel Negeri van Oranje karya Wahyuningrat dkk.

\begin{tabular}{|l|l|l|}
\hline $\begin{array}{c}\text { Klasifikasi } \\
\text { Perbandingan }\end{array}$ & $\begin{array}{c}\text { Holland: One } \\
\text { Fine Day in } \\
\text { Leiden }\end{array}$ & \multicolumn{1}{|c|}{$\begin{array}{c}\text { Negeri van } \\
\text { Oranje }\end{array}$} \\
\hline Judul & Terlalu panjang & Singkat dan jelas \\
\hline Jumlah halaman & 300 halaman & 575 halaman \\
\hline Statement & Tidak ada & $\begin{array}{l}\text { Andrea Hirata, } \\
\text { Raditya Dika, } \\
\text { dan Trinity }\end{array}$ \\
\hline Penerbit & Bukune & Bentang Pustaka \\
\hline Tahun Terbit & 2013 & 2009 \\
\hline Penulis & Satu Orang & Empat orang \\
\hline Keberlanjutan & Belum ada & $\begin{array}{l}\text { Dua kali cetak, } \\
\text { Difilmkan } \\
\text { (dalam proses) }\end{array}$ \\
\hline
\end{tabular}

Melalui bagan di atas, maka dapat kita bandingkan beberapa klasifikasi sebagai upaya pemetaan arena antara kedua novel. Pada klasifikasi pertama, yaitu dalam hal judul, novel Holland: One Fine Day in Leiden terlalu panjang dengan penggunaan Bahasa Inggris yang relatif sulit dipahami artinya, terutama dalam hal mencerminkan representasi isi cerita. Hal itu selain berdampak pada kesulitan mengingat nama judul dan dalam hal pengucapan, pengambilan nama kota Leiden yang relatif kurang popular untuk pembaca Indonesia (kecuali para mahasiswa budaya dan hukum) berdampak pada kurangnya gambaran mengenai pokok penceritaan. Mengingat program yang ingin diangkat oleh penerbit, yaitu dalam konsep Setiap Tempat Punya Cerita, yang tentu terkait dengan pembaca popular, wawasan mereka terhadap nama Leiden dan judul yang terlalu panjang membuatnya kurang menarik bagi pembaca awam yang menjadi sasaran dari penerbitan novel ini. Meski menggunakan nama Holland pada kata pertama dalam judul yang juga mengasosiasikan mengenai Belanda, tetapi judul yang terlalu panjang dan pengangkatan ikon kota Leiden yang kurang dikenal secara umum oleh masyarakat Indonesia tentu memiliki korelasi dengan penjualan novel tersebut.

Berbeda dengan novel Negeri van Oranje karya Wahyuningrat, dkk. Novel ini memiliki judul yang singkat dan ikonik. Artinya, konjungsi "van" yang dikenal sangat ikonik dengan nama Belanda dan pemilihan "Oranje" sebagai pengganti nama Belanda yang sama-sama memiliki asosiasi dengan Belanda, memiliki poin yang menarik dalam hal pengemasan judul. Pengemasan judul merupakan strategi marketing sebuah karya atau buku karena dalam hal ini asosiasi yang dimunculkan dari judul dalam novel tersebut relatif jelas, yaitu mengenai Belanda.

Perbedaan antara novel Holland: One Fine Day in Leiden dan Negeri van Oranje dalam hal pengemasan judul lebih mengarah pada tingkat kemudahan pembaca dalam menebak isi atau bahasan dalam novel. Artinya, representasi mengenai judul yang mencerminkan isi cerita sangatlah penting. Selain karena judul yang terlalu panjang bila dibandingkan dengan Negeri van Oranje, representasi dari isi dalam novel Holland: One Fine Day In Leiden relatif sulit ditebak oleh pembaca Indonesia pada umumnya karena kota Leiden tidak terlalu familiar seperti Amsterdam misalnya. Di sisi lain, julukan tim nasional Belanda dengan 


\section{Jurnal Poetika Vol. III No. 2, Desember 2015}

nama tim Oranje tentu memudahkan pembaca dalam hal memahami pokok penceritaan dalam novel, yaitu mengenai Belanda, dimana olahraga nomor satu di Indonesia adalah sepak bola. Artinya, sebelum pembaca menikmati indahnya narasi dalam cerita, ketertarikan utama yang harus dimunculkan dalam sebuah novel tentu tidak hanya keindahan desain dari sampul novel tersebut, tetapi juga keberhasilan judul tersebut dalam menyampaikan informasi mengenai isi terhadap calon pembaca.

Pada klasifikasi perbandingan kedua adalah mengenai jumlah halaman. Novel Holland: One Fine Day in Leiden berjumlah 300 halaman. Dengan demikian, novel ini relatif lebih menarik bagi pembaca karena sering kali tingkat ketebalan halaman menjadi pertimbangan khusus bagi calon pembaca untuk tertarik dan mau membaca sebuah novel. Berbeda dengan novel Negeri van Oranje yang berjumlah 575 halaman atau secara fisik terlihat tebal, sering kali membuat pembaca enggan untuk membacanya karena membutuhkan waktu yang cukup lama.

Klasifikasi perbandingan ketiga adalah mengenai statement. Dalam hal ini Negeri van Oranje memiliki statement dari tiga tokoh sastrawan yang sangat familiar, yaitu Andrea Hirata penulis tetralogi Laskar Pelangi, Raditya Dika penulis Kambing Jantan dan tokoh Stand Up Comedy Indonesia, dan Trinity penulis The Naked Traveler Series. Dalam hal ini, penilaian yang diberikan oleh ketiga tokoh dalam statement pada bagian sampul novel tersebut memberikan legitimasi terhadap novel tersebut. Robert Escarpit (2005) menjelaskan pentingnya afiliasi. Artinya, statement tersebut berfungsi sebagai modal novel Negeri van Oranje untuk lebih laku dan diminati oleh pasar. Berbeda dengan novel Holland: One Fine Day in Leiden yang tidak menerapkan hal tersebut sehingga tingkat popularitas dan legitimasi terhadap novel tersebut tidak setinggi novel Negeri van Oranje.

Klasifikasi perbandingan berikutnya adalah mengenai Penerbit. Dalam hal ini, Negeri van Oranje dengan Bentang Pustaka sebagai penerbitnya tampak lebih baik dalam memasarkan produknya. Secara historis memang penerbit ini telah menelurkan karya-karya besar seperti tetralogi Laskar Pelangi karya Andrea Hirata dimana karya-karya Andrea Hirata bisa disebut sebagai karya yang telah mendunia. Meski Gagas Media dan Bukune juga merupakan penerbit yang cukup besar di Indonesia, tetapi penerbit ini tidak memiliki barometer karya yang cukup fenomenal. Artinya, Negeri van Oranje bersama Bentang Pustaka lebih memiliki kans untuk laris di pasaran karena telah berada dalam sistem marketing yang baik dalam hal pemasarannya. Statement penulis-penulis yang berafiliasi dengan Bentang Pustaka seperti Andrea Hirata maupun Raditya Dika, seolah menjadi strategi marketing tersendiri yang tampaknya ingin difungsikan untuk mendongkrak popularitas Negeri van Oranje. Terlebih, novel ini juga digarap oleh Mizan Media Utama sebagai distributor yang sama pula dengan tetralogi Laskar Pelangi.

Klasifikasi perbandingan keenam adalah mengenai tahun terbit. Mengingat novel Holland: One Fine Day in Leiden baru terbit pada tahun 2013, tanpa sistem promosi dan strategi pemasaran yang baik, maka Negeri van Oranje tentu lebih memiliki popularitas. Saat ini, Negeri van Oranje sudah terbit untuk kedua kalinya, yaitu pada April 2009 dan Juni 2014. Korelasinya, mengingat Negeri van Oranje sudah lebih lama di pasaran dan sudah terbit untuk kedua kalinya, tentu memberikan indikasi bahwa novel ini sudah banyak berada di tangan pembaca. Berbeda dengan novel Holland: One Fine Day in Leiden yang baru saja terbit dan tidak memiliki sistem marketing sebagus terbitan Bentang Pustaka, popularitas novel ini masih relatif kurang.

Klasifikasi perbandingan ketujuh mengenai penulis. Baik novel Holland: One Fine Day In Leiden maupun Negeri van Oranje adalah sama-sama ditulis oleh pendatang baru dalam kesusastraan Indonesia. Titik menariknya adalah upaya pemasaran keduanya di luar penerbit. Kerja tim yang dilakukan oleh Wahyuningrat dan kawan-kawan tentu lebih 
optimal bila dibandingkan dengan kerja Feba Sukmana seorang diri. Mengingat, seperti yang telah dijelaskan sebelumnya, keduanya adalah pendatang baru dalam kesusastraan Indonesia.

Klasifikasi perbandingan selanjutnya adalah mengenai keberlanjutan dari novel-novel tersebut. Saat ini, Negeri van Oranje sedang dalam proses pembuatan film. Dalam hal ini, ada korelasi tentunya dengan umur novel yang relatif lebih lama, judul novel yang lebih marketable, dan publikasi yang baik oleh penerbitnya, yang membuat novel ini cukup menjanjikan untuk dilirik industri lain. Terlebih lagi, belum adanya film Indonesia yang mengangkat tema cerita dengan latar Belanda. Novel Holand: One Fine Day in Leiden belum ada keberlanjutan, baik dalam hal difilmkan, dicetak ulang, maupun terbitnya dwilogi dari novel tersebut.

Terkait hubungan antara modal dan babitus Feba Sukmana dalam kontestasinya dengan penulis lain yang sama-sama menuliskan cerita mengenai Belanda, dapat dilihat kurangnya marketing Feba Sukmana sebagai seorang penulis. Selain terkait sistem pemasaran yang dilakukan oleh penerbit novelnya kurang maksimal, Feba Sukmana sebagai seorang penulis sejak kecil tidak terbiasa bergabung dengan kelompokkelompok sastra, sehingga popularitasnya di mata sastrawan kurang dan tentu berdampak pula pada popularitasnya di mata pembaca umum.

Praktik: Implementasi Modal-Modal Feba Sukmana Penulis Novel Holland: One Fine Day In Leiden melalui Narasi Cerita dan Penggunaan Bahasa

Pada bagian ini, implementasi dari modal-modal yang dimiliki oleh Feba Sukmana sebagai seorang penulis akan dilihat dalam aspek narasi dan penggunaan bahasa. Pertama tentu terkait modal kulturalnya dimana ia terlahir dari keluarga seni yang membuatnya terbiasa dengan membaca buku cerita dan menulis diary. Kedua terkait modal pendidikannya, yaitu ketika ia studi pada jurusan Sastra Belanda di Universitas
Indonesia dan S2 di Leiden University. Ketiga, terkait babitus yang ia bangun, baik ketika kecil maupun ketika ia akhirnya menulis novel Holand: One Fine Day in Leiden. Dalam hal ini, analisis tidak hanya dilihat dalam keterkaitan dengan aspek sosiologis yang menekankan pada habitusnya, narasi yang ia bangun dalam cerita, tetapi juga terkait dengan penggunaan bahasa di dalam novelnya.

Dalam hal narasi, novel Holland: One Fine Day in Leiden cukup baik menggambarkan seting lokasi, alur cerita, maupun dalam hal deskripsi tokoh. Tampaknya, hal ini memiliki implementasi dengan kebiasaan Feba Sukmana menulis diary semenjak kecil. Kebiasaan itu telah menjadi modal yang baik dalam penceritaan di dalam novelnya. Di sisi lain, terkait dengan narasi mengenai Belanda, modal pendidikannya ketika studi S1 di Universitas Indonesia jurusan Sastra Belanda maupun ketika sudah di Belanda sejak tahun 2007 hingga tahun 2013 dimana novelnya selesai ia garap, memiliki korelasi terhadap tingkat keidentikan cerita dengan narasi yang ia bangun, yaitu mengenai Belanda. Kualitas penceritaan yang baik dan keterampilan Feba Sukmana dalam hal bercerita lahir karena habitus dimana hal tersebut terbangun oleh modalmodal yang dimiliki Feba Sukmana, yakni modal kultural ketika masih berada dalam keluarganya dan modal pendidikan terkait studi yang ia ambil.

Hubungan modal pendidikan Feba Sukmana dengan keterampilannya dalam hal dunia tulis-menulis tentu tercermin ketika ia menyelesaikan gelar sarjananya di Universitas Indonesia dan masternya di Universitas Leiden. Mengingat baik Universitas Indonesia maupun Leiden University adalah dua universitas yang memiliki reputasi yang baik, tentu memiliki hubungan kausalitas yang ganda terhadap Feba Sukmana. Pertama karena ia berada dalam lingkup studi di Universitas yang baik maka berdampak pada tingkat intelektualitasnya. Di sisi lain, ketika masih studi S1 di Universitas Indonesia, Feba Sukmana telah memiliki kesempatan untuk short course pada salah satu universitas di Belanda 


\section{Jurnal Poetika Vol. III No. 2, Desember 2015}

dengan syarat mahasiswa yang dikirim memiliki rangking 3 teratas nilai IPK tertinggi dalam kelas. Kesempatan short course karena ia studi pada salah satu kampus dengan sistem pengelolaan yang baik. Dengan demikian, tingkat keilmuwan Feba Sukmana sudah terbentuk sejak masih studi di Universitas Indonesia. Terlebih beasiswa yang ia peroleh untuk studi master di Leiden University dalam kajian yang sama, menunjukkan garansi dalam hal kemampuannya ketika ia akhirnya menuliskan narasi mengenai Belanda.

Kaitan penggunaan bahasa dan modal yang ia miliki adalah terkait dengan pemilihan bahasa maupun kosa kata di dalam novelnya. Feba Sukmana dengan baik bisa mengkomparasikan penggunaan Bahasa Indonesia baku dalam narasi, penggunaan bahasa Inggris dan Belanda dalam hal dialog antartokoh, maupun sisipan Bahasa Indonesia gaul dalam dialognya. Artinya, meski dapat kita curigai adanya campur tangan dari editor, tetapi melihat habitus yang ia miliki, baik dalam hal modal kultural maupun modal pendidikan, tulisannya bisa diasumsikan lahir secara murni karena kualitas atau kemampuan dirinya sebagai seorang penulis. Hal itu tentu tidak berlebihan mengingat dirinya adalah mahasiswa jurusan sastra yang studi pada salah satu kampus terbaik di Indonesia dan kemampuan berbahasa asing (Inggris) yang baik terlebih studi masternya di luar negeri dimana proses penerimaannya tentu mensyaratkan sejumlah kriteria ketat, tak terkecuali dalam hal kemampuan berbahasa.

Di bawah ini adalah contoh penggunaan Bahasa Indonesia dan bahasa asing yang cukup baik di dalam novel tersebut. Bagian ini tentu terkait dengan korelasi pendidikan dan bahasa yang dimiliki oleh agensi yang berkoralasi dengan pemikiran Bourdieu. Dalam hal ini, permasalahan bahasa yang dibahas tentu terkait dengan penggunaan bahasa dalam khasanah kebahasaan Indonesia mengingat novel tersebut merupakan bagian dari kesusastraan Indonesia.

“...Namun, kala senja membingkai Leiden dengan jingga yang memerah, Kara masih ingat bisik manis laki-laki bermata pirus itu, "Ik vind je leuk"- —aku suka kamu. Juga kecup hangatnya. Rasa takut mengepung Kara, takut jatuh cinta kepada seseorang yang akhirnya akan pergi begitu saja. Dan, meninggalkan perih yang tak tersembuhkan waktu. Seperti Ibu.", (Sukmana, 2013)

Pada kutipan di atas, deskripsi narator menggunakan Bahasa Indonesia baku. Sisipan bahasa asing dalam hal ini Bahasa Belanda dicetak dengan huruf miring, dan oleh karena kalimat langsung, maka diawali dan di akhiri dengan tanda kutip. Penambahan penerjemahan ke dalam Bahasa Indonesia -aku suka kamu, merupakan keharusan mengingat novel ini ditulis dalam Bahasa Indonesia. Selain agar pembaca lebih mudah memahami arti dari kalimat tersebut, hal ini merupakan bagian dari aturan penulisan dalam Bahasa Indonesia.

\section{Kesimpulan}

Korelasi antara modal Feba Sukmana sebagai seorang penulis, baik dalam hal modal kultural maupun modal pendidikan, sangat kuat dalam hubungannya dengan karyanya. Kondisi keluarganya yang dekat dengan dunia seni, kebiasaannya membaca buku cerita, dan kebiasaannya menulis diary merupakan modal kultural yang menjadi habitus Feba Sukmana sebagai seorang penulis, terlebih dalam hal ini novel Holland: One Fine Day in Leiden adalah karya yang dipesan oleh redaktur sebuah penerbit yang merupakan teman kuliahnya. Modal pendidikannya terkait dengan aktivitasnya sejak masih SMP dalam pengiriman puisi-puisi yang termuat pada majalah dinding maupun cerpen ketika sudah SMA. Dalam hal ini, keterampilannya mengenai dunia tulis-menulis terkait pula dari habitusnya sejak kecil, baik diawali dalam hal membaca cerita maupun menuliskan diary hingga menuliskan puisi dan cerpen pada mading sekolah.

Kontestasi Feba Sukmana dengan penulis lain terefleksi di dalam novel Holland: One Fine Day In Ledien dan novel Negeri van Oranje, terkait pula kurangnya Feba Sukmana dalam hal bergaul 
dengan komunitas-komunitas sastra yang ada di Indonesia. Hal ini penting karena dukungan dari komunitas-komunitas sastra merupakan strategi yang baik dalam pengembangan pasar dari karya-karyanya. Terlebih dengan kondisi penerbit novel tersebut kurang memiliki karya yang bisa dijadikan barometer dan tidak memiliki sistem promosi maupun marketing yang bagus, menjadikan novel yang baru terbit pada tahun 2013 ini relatif belum bisa menandingi popularitas novel Negeri van Oranje dalam arena yang sama, yaitu tema mengenai Belanda dan konsep penceritaan berdasarkan pengalaman penulis. Terlebih selain karena tahun terbit yang lebih lama, Negeri van Oranje memiliki judul yang marketable dan sudah dalam proses pembuatan film yang barang tentu akan semakin mendongkrak popularitas novel tersebut.

Hubungan antara dunia pendidikan dan penggunaan bahasa sebagai bagian penting dalam kaitan antara modal dan praktik seorang penulis terletak pada penggunaan bahasa dan pemilihan diksi yang baik sebagai sarana penceritaan pada karyanya. Hubungan ini tentu terkait dengan kualitas pendidikan yang dimiliki oleh Feba Sukmana, baik ketika masih studi S1 jurusan Sastra Belanda di Univeritas Indonesia maupun ketika sudah studi master di Leiden University. Dalam hal ini, hubungan bahasa dan modal Feba Sukmana terutama modal pendidikan memiliki korelasi yang kuat terhadap kemampuannya membangun narasi, mendeskripsikan suatu keadaan, dan penggunaan bahasa asing seperti Inggris dan Belanda.

\section{Daftar Pustaka}

Escarpit, Robert. 1958. Sociologie De La Litterature. Kata Pengantar Sapardi Djoko

Damono. 2005. Sosiologi Sastra. Jakarta: Yayasan Obor Indonesia.

Harker, Richard. 1990. "Bourdieu-Pendidikan dan Reproduksi”. Dalam (Habitus × Modal) + Ranah $=$ Praktik. Pengantar Paling Komprehensif Kepada Pemikiran Pierre
Bourdieu. 2009. Editor Richard Harker, Cheelen Mahar, dan

Chris Wilkes. Yogyakarta: Jalasutra.

Sukmana, Feba. 2013. Holland: One Fine Day In Leiden. Jakarta Selatan: Bukune.

Takwin, Bagus. 2009. (Habitus $\times$ Modal) + Ranah = Praktik.

Pengantar Paling Komprehensif kepada Pemikiran Pierre Bourdieu. Yogyakarta: Jalasutra.

Wahyuningrat, dkk. 2014. Negeri van Oranje. Jogjakarta: Bentang Pustaka.

Wilkes, Chris. 1990. "Kelas Menurut Bourdieu”. Dalam (Habitus $\times$ Modal) + Ranah $=$ Praktik. Pengantar Paling Komprehensif Kepada Pemikiran Pierre Bourdieu. 2009. Editor Richard Harker, Cheelen Mahar, dan Chris Wilkes. Yogyakarta: Jalasutra. 